\title{
Responsible Metal Detecting
}

\section{Thomas, Suzie}

Wiley

2018-12-05

Thomas, S 2018 , Responsible Metal Detecting . in S Lopez Varela \& G Fairclough (eds), The SAS Encyclopedia of Archaeological Sciences . Wiley . https://doi.org/10.1002/9781119188230.saseas0507

http://hdl.handle.net/10138/298904

https://doi.org/10.1002/9781119188230.saseas0507

acceptedVersion

Downloaded from Helda, University of Helsinki institutional repository.

This is an electronic reprint of the original article.

This reprint may differ from the original in pagination and typographic detail.

Please cite the original version. 
Responsible Metal Detecting

SUZIE THOMAS

University of Helsinki, Finland

In The SAS Encyclopedia of Archaeological Sciences. (2018).DOI 10.1002/9781119188230.saseas0507

Among the different forms of artifact hunting, hobbyist metal detecting has been of particular interest in recent years to researchers, especially in regions such as northern Europe where metal artifacts are in relative abundance and where laws do not prohibit metal detecting. Countries that have fuller restrictions, such as Cyprus (Hardy 2014), often also have more extensive state intervention regarding cultural heritage in general, such as the state ownership of cultural objects, or have experienced an incident that has affected opinion concerning the acceptability of metal detecting as a hobby, as with Ireland (Kelly1993).

Metal detecting emerged as a hobby in which members of the public could partake, in countries such as the United Kingdom and the United States in the 1960s, although metal-detecting devices-originally developed in the military for mine searching-had been available before then. There is evidence of archaeologists trying metal detectors in the mid-twentieth century, such as in England in 1948 (Hobbs 2003,18 ) and the United States in 1958 (Connor and Scott 1998, 76). Despite early tests of the efficacy of metal detectors as archaeological survey tools, the devices have attracted controversy, especially in the 1970s and 1980s, with the rapid growth of hobbyist metal detecting (Thomas 2012). Incidences of looting using metal detectors, as well as tensions around the different ontologies adopted by archaeologists and other heritage professionals, and within the metal-detecting community itself, have led to conflict at different times, sometimes spilling over into broader political debates about heritage management policy.

In some countries, such as Sweden, Russia, and France, it is illegal to metal detect. This does not necessarily prevent looting, which is still a problem in many places where metal detecting is not permitted. Some countries, such as Estonia, permit metal detecting provided the metal detectorist has applied, and fulfilled the criteria, for an official license. In other countries, such as Denmark and the United Kingdom, metal detecting is legal in many circumstances (although certain areas of land may be protected, for example if designated as a site of archaeological significance). In situations where metal detecting is permitted, hobbyists are nonetheless required to meet their legal obligations: in most cases, including New Zealand and Finland, hobbyists should not disturb known archaeological sites, and in many countries there are various levels of mandatory reporting of finds. Furthermore, the use of metal detectors in a hobbyist capacity not only relates to the search for archaeological material: Internet discussion forums in Australia and New Zealand indicate that gold prospecting is a major goal of hobbyists in those countries, for example. The legal requirements for finds recording thus vary from jurisdiction to jurisdiction, although responsible metal detectorists would be expected to report not only the objects that the law requires them to report, but also other archaeological and historical material.

Beyond often basic legal requirements, it is clear that the practices of hobbyist metal detectorists put many more objects of archaeological significance at risk. Therefore, in many jurisdictions where metal detecting is permitted, hobbyists are also encouraged to practice their hobby responsibly, to ensure that more archaeologically useful information can be gathered from their discoveries. Critics of metal detecting argue that the removal of objects by untrained detectorists cannot ever be at a standard comparable to that of a scientific investigation (e.g., Gill2010); others have acknowledged that in certain circumstances —such as 
areas where land has already been plowed or otherwise disturbed-and with a responsible approach, it is still possible to salvage scientifically useful information (e.g., Kershaw2013).

Responsible metal detecting is generally interpreted as the behavior, or best practice, of metal detectorists who adhere to a set of standard procedures to ensure that the archaeological context of what they find is adequately and accurately recorded, and reported to the correct authorities. This may mean reporting to a local or national museum, a national heritage authority, or other organization with designated responsibility for recording finds, depending on the country or region. There are also legal restrictions on the movement of certain cultural objects across national borders, which may affect detectorists who practice their hobby in more than one country.

In England and Wales, mandatory reporting is limited only to a few categories of finds that are defined as "treasure" in the Treasure Act 1996. Since 1997, this law has been complemented by the Portable Antiquities Scheme (PAS), which began as a pilot project in six regions and was later rolled out across the whole of England and Wales. Various organizations-representing both archaeologists and metal detectorists - have contributed to and shared a Code of Responsible Metal Detecting, which was agreed and published in 2006 and updated in 2017 (https://finds.org.uk/getinvolved/guides/codeofpractice), and the PAS maintains a network of Finds Liaison Officers to whom detectorists are strongly urged to report finds of all types of archaeological artifacts so they can be identified and recorded scientifically.

Among the ways to be "responsible" according to the Code are"[r]ecording findspots as accurately as possible for all finds (i.e. to at least a one hundred metre square, using an Ordnance Survey map or handheld Global Positioning Systems (GPS) device) whilst in the field." If it appears that the discovery is something more significant than a stray find - such as a hoard of artifacts or possible part of an archaeological site-metal detectorists should refrain from further excavation and contact the heritage authorities.

Many organizations also offer advice to metal detectorists on how best to conserve their finds. The crucial element of accurately recording finds with an archaeologist, as well as refraining from "cleaning" the artifacts (which will remove further contextual information from the object), has led in recent years to various countries developing their own digital databases specifically for handling the finds data that metal detectorists and other artifact collectors have available. In addition to PAS, which began its activities in 1997 in England and Wales and has curated a finds database from its outset, in recent years databases have come into development for Flanders, Belgium, the Netherlands, and Denmark. Several other European countries are in the process of developing proposals for finds recording schemes, and there are also discussions underway in some US states for state-wide recording schemes.

In addition to "responsible" behavior - meeting minimum standards in recording, conserving, and reporting their finds-Shott and Pitblado $(2015,12)$ have suggested that there are also "responsive" collectors (including detectorists) that have the potential to act responsibly, pending being made aware of how their collecting activities relate to archaeological practice: "We believe that collectors who meet these minimal standards are responsible, and those who might meet them after being educated are responsive."

Therefore, while some metal detectorists may currently not be practicing their hobby in a way that makes a significant contribution to archaeological research, they may nonetheless be receptive to encouragement to metal detect in a more responsible manner, by way of advice, outreach education, and training. In Scotland, a recent series of posters and leaflets published by the Scottish Treasure Trove Unit appears to have encouraged improved finds reporting from metal detectorists and others, by highlighting what kinds of objects from different historical and archaeological periods are of interest to the Unit, and giving visual representations of how such objects typically look. 
Future research around the theme of hobbyist metal detecting and its impact on archaeology seems to be developing in a number of different directions. Although much research about hobbyist metal detectorists has already taken place within national contexts - notably in the United Kingdom but also elsewherethere is arguably a need for a yet deeper understanding of the motivations of the hobbyists themselves, which in turn may assist strategies intended to promote and encourage responsible behavior. Unlawful metal-detecting activities also continue to be a cause for concern, for example operating metal detectors in jurisdictions where it is not permitted, or not having a license in countries where it is a requirement to have one, as well as looting archaeological sites for saleable objects. In many cases, understanding the scale of these issues is impeded by a lack of robust data - exacerbated by the clandestine nature of many of these activities.

Research projects-including doctoral dissertations but also larger-scale studies-are increasingly making use of metal-detected data. This has led to the discovery of new artifact types, studies of finds distributions over landscapes, and even identification of previously unknown or not located battlefield sites and other categories of site previously less well documented. As more digital finds databases develop, there will be challenges to ensure that these digital data are compatible across databases and systems, in order to enable and enhance transnational research questions.

In addition, ethical challenges within digital finds recording include providing open-access data to researchers from within and outside of institutional academia, without compromising the security of findspots and sites: Vulnerability to looting is a serious issue to consider. Because of this, restrictions are sometimes placed on the details regarding finds location that individual users are able to access. Opportunities for research using finds databases that share information provided by metal detectorists appear to have the potential to develop further research questions and projects to utilize these "big data" as they become more readily available and accessible.

\section{REFERENCES}

Connor, Melissa, and Douglas D. Scott. 1998. "Metal Detector Use in Archaeology: An Introduction." Historical Archaeology 32 (4): 76-85. DOI:10.1007/bf03374273.

Gill, David. 2010. "The Portable Antiquities Scheme and the Treasure Act: Protecting the Archaeology of England and Wales?" Papers from the Institute of Archaeology20:1-11.DOI:10.5334/pia.333.

Hardy, Sam. 2014. "Threats to Cultural Heritage in the Cyprus Conflict." In Heritage Crime: Progress, Prospects and Prevention, edited by Louise Grove and Suzie Thomas, 81-104. Basingstoke, UK: Palgrave Macmillan.

Hobbs, Richard. 2003. Treasure: Finding Our Past. London: The British Museum Press.

Kelly, Eamon. 1993. "Treasure-Hunting in Ireland: Its Rise and Fall." Antiquity 67 (255): 378-81. DOI:10.1017/S0003598X00045440.

Kershaw, Jane. 2013. Viking Identities: Scandinavian Jewellery in England. Oxford: Oxford University Press.

Shott, Michael, and Bonnie Pitblado. 2015. "Introduction to the Theme 'Pros and Cons of Consulting Collectors'." The SAA Archaeological Record 15 (5): 11-13, 39. Accessed January 24, 2018. http://www.saa.org/Portals/0/SAA_Record_Nov2015.pdf. 
Thomas, Suzie. 2012. "Archaeologists and Metal-Detector Users in England and Wales: Past, Present and Future." In The Oxford Handbook of Public Archaeology, edited by Robin Skeates, Carol McDavid, and John Carman, 60-81.0xford: Oxford University Press.

\section{FURTHER READINGS}

Campbell, Stuart, and Suzie Thomas, eds. 2013. "Portable Antiquities: Archaeology, Collecting, MetalDetecting."Special Issue, Internet Archaeology 33. Accessed January 24, 2018. http://intarch.ac.uk/journal/issue33/index.html.

Deckers, Pieterjan, Michael Lewis, and Suzie Thomas, eds. 2016. "Topical Issue on Aspects of NonProfessional Metal Detecting in Europe." Special Issue, Open Archaeology 2 (1). Accessed January 24, 2018. http://degruyteropen.com/tioparasnmde/.

Hole, Brian, ed. 2010. "Forum." Papers from the Institute of Archaeology 20. Accessed January 24, 2018. http://www.pia-journal.co.uk/3/volume/20/issue/0/.

Thomas, Suzie, and Peter G. Stone, eds. 2009. Metal Detecting and Archaeology. Woodbridge, UK: Boydell Press. 